clause, where the general board only certifies to the suppression of graveyards. I suppose, however, this certificate will be from the two or three great guns of our profession in that board. But was there ever a greater injury? Again: fancy the idea of a certificate of the general board to suppress a known nuisance, when that of a chimney-sweep will answer in those more difficult to discover.

I shall make no further apology, and will, should you think proper to move an officer-of-health clause in committee, undertake to pray for the support of our worthy representative the Lord George Bentincl.

Lynn, Feb. 18t8.

$$
\text { Yours, faithfully, GEo. SArLk, }
$$

Surgeon to the West Norfolk Hospital.

\section{THE ODIOUS INCOME-TAX.}

[LETTER FROM DR. WILSON, OF ST. GEORGE'S HOSPITAL.]

$$
\text { To the Editor of The Lancer. }
$$

Sir,-It secms to me that I should be failing in my duty,I am sure that I should not be true to my own feelings, -if I did not thank you at once, and cordially, for the shrewdness, talent, and earnestness, with which, in the two last numbers of Tre Lascet, you have denounced the levy by those in power of three per cent. on our hard professional earnings. On your invitation, Sir, and in the common interest, $I$ am ready to sign my name to any petition, remonstrance, or protest, against the stupid injustice contemplated by the financial leaders of the House of Commons, in their coalition for the continuance of an unmodified tax upon income. Ah! when will these so called "statesmen" condescend to the child's wisdom, that injustice is still and ever folly? To those who stand aloof and watch, how dangerous, how terribly dangerous, is this determination of the British government, that, in 1848-49-50, the precarious gains of a professional life should be surcharged tenfold or more, on an interminable annuity for the relief of the idle and luxurious rich! Again I thank you, Sir, for the manly stand which, both in and out of Parliament, you have made against this beginning of revolution in our money-loving yet fair-dealing England. Would that you were cheered in your generous task, by a sign, a word of encouragement from our chartered professional colleges, or from individual "heads of the profession," whose interests and dignity you maintain in this matter, as strictly identical with those of the public at large.

Believe me, Sir, your faithful servant, London, March, 1849. J AMES ARTuUr WiLson, M.D.

\section{POOR-LAW MEDICAL INSPECTORS. To the Editor of THE LANCET.}

SIR,-In THE LANCET of the 27 th inst., there are some suggestions by Dr. Garrett Dillon, concerning the appointment of deputy medical inspectors, under the poor-law, and I cannot rest until I have warned every poor-law medical officer to memorialize the government against it, should such a proposition ever be laid on the table of the House of Commons. I consider the union medical officers have sufficient to contend against already, without having another competitor brought into the field, in the shape of a government stipendiary, with the influence which the " pomp and circumstance" of the appointment, and the aid of the salary, would give him. I "fully agree" with Dr. Garrett Dillon, that it would be a very nice thing to have the pay of a deputy inspector of hospitats, and to be allowed to skim the cream of the practice of four unions, leaving the union surgeon the ten-shilling midwifery cases, and the pleasure of dispensing. I have not time, to-day, to reply to the whole of the Doctor's suggestions, but should ever such a job as this be seriously contemplated, I feel convinced you will denounce it as it ought to be, not only in The Lancet, but in the House of Commons, should it ever be brought forward there.-I am, Sir, your obedient servant,

Kineton, Warwickshire, Feb. 1818 .

JoHn Epmunds.

\section{THE FATAL CHLOROFORM CASE AT NEWCASTLE. To the Editor of TH Larcer.}

Srr,-Dr. Simpson's extraordinary letter, which appeared in THE LANCET for the 17 th ultimo, seems to have called forth a host of commentators; as the subject is not exhausted, I trust you will find place for the following remarks.

Chloroform and ether have been generally considered to exert their paralyzing influence exclusively on the true "cerebral" system of nerves, leaving the true spinal and ganglionic systems unaffected, therefore, according to this view, neither of these agents could be supposed to impede in any way the act of deglutition, which has been proved by the experiments of that great pioneer of science, Dr. Marshall Hall, to be entirely of an excito-motory character; but in this unfortunate case, Dr. Simpson ascribes the cause of death to the suspension of that function, or rather, to the admission of fluid into the larynx consequent upon it. Does Dr. Simpson really admit that chloroform has the power of suspending true spinal actions? or does he believe in another theory of the nervous system than that of Dr. Marshall Hall? He seems to consider deglutition as an act of volition.

That syncope should have occurred from a slight operation in a person already under the influence of chloroform is not very probable, and had the spinal system been deadened for a time from that cause, still with the return of the circulation it would have been the first to act, and would have removed from the pharynx the fluid which Dr. Simpson considers to have been the immediate cause of death.

Would it not have been more physiological to have said, that this poor woman's death was owing to the power which anæsthetic agents have, in some very rare instances, of destroying the functions of the spinal and ganglionic systems of nerves; such a construction would at least have been more liberal towards the gentleman who attended the case.

The world undoubtedly owes a great deal to Dr. Simpson for the discovery of the properties of chloroform, but like many a spoiled fondling, that agent $I$ am afraid will suffer from the too great affection of a doting parent.

I remain, Sir, yours very respectfully,

David Davres, House-Surgeon.

Dispensary, Loughborough, March, $18 * 8$.

\section{GRADUATES OF THE UNIVERSITY OF LONDON. \\ To the Editor of The Lancet.}

Sre,-I was pleased with the general tenor of Dr. Humble's letter in The LANCET of last week, calling upon the medical graduates of the University of Iondon to exert themselves at this juncture, in the cause of medical reform, and in opposing the insidious movements of certain corporate institutions, in conjunction with the so-called National Institute.

Dr. Humble boldly asserts the social or civil dignity of M.D.s; but this, alas! has become a mere matter of history, and one to be talked about only by the antiquary, seeing that M.D.s of spurious or of free and easy German or Scotch origin are so numerous, to whom no one could accord any dignity or courtesy, but who are, nevertheless, in the present chaotic confusion of medical politics, mixed up indiscriminately with those whose degrees are an honour to themselves. Allowing with Dr. Humble the high value to be set upon degrees conferred by the University of London, yet I consider the condition of that university to be, in many points, most unsatisfactory to its now numerous graduates. $\bar{I}$ would at present allade to only one circumstance in the constitution of that university, but one which has relation to Dr. Humble's letter-viz., the want of any association, of any bond of union, between the University and its graduates. In this point, the University may be likened to a shop, at which one can purchase an article at a given price, and upon certain conditions, but having made your purchase, all further connexion or relationship ceases. 'To a man having paid his fee, and passed his examination, (as he learns by a notification in a room of the University, or from a newspaper paragraph,) may, after a short interval, apply at the office of the institution and get a certificate or diploma, witnessing his admission to the degree. This done, he has nothing further to do with the University, and the latter concerns itself no more about him. Such an anomalous condition requires to be remedied. Whilst it lasts, the call of Dr. Humble upon its graduates to "communicate seriously with their chancellor and fellows on the one hand, and with the Government on the other; to impress on the senate the necessity for active co-operation on the part of the heads of the University," \&c., although excellent in its object, must vanish into empty air. But I can join with him when he says, "let us lose no more time, but forthwith organize ourselves;" and I would add, let us, when organized, use our energies to bring about first a rational constitution for our alma mater, and then act together in the cause of the reform of the medical profession.

But whether organized or not, I think I may safely say that London medical graduates will one and all oppose that foolish device, the incorporation of the self-styled National Institutenational on the principle of lucus a non lucendo. Such a measure would be a step towards the further degradation of the profession, and hence, quite a work of supererogation - a measure as rational as would have heen the incorporation as a university of the extinet British and Foreign Institute, (better known as the 